\title{
PENGARUH KONSENTRASI DAN LAMA PERENDAMAN ASAM LAKTAT TERHADAP KADAR GLUKOSA DAN KUALITAS TEPUNG GARUT ( Maranta arundinacea $\mathrm{L}$ )
}

\author{
Nasrul Rofiah Hidayati \\ Program Studi Pendidikan Biologi FPMIPA IKIP PGRI Madiun \\ nasrul.rofiah@gmail.com
}

\begin{abstract}
ABSTRAK
Penelitian ini bertujuan untuk mengetahui adanya pengaruh konsentrasi dan lama perendaman asam laktat terhadap kadar glukosa dan kualitas tepung garut (Maranta arundinacea L). Metode penelitian menggunakan Rancangan Acak Lengkap (RAL) dengan factorial $3 \times 3$ dan tiga kali ulangan. Faktor pertama variasi konsentrasi $(\mathrm{K})$ meliputi 1\%, 1,5\%, 2\%, factor kedua lama perendaman (L) meliputi 60 menit, 90 menit, 120 menit. Pengambilan data dengan menghitung kadar glukosa menggunakan metode titrasi menggunakan $\mathrm{Na}_{2} \mathrm{~S}_{2} \mathrm{O}_{3}$ dan uji organoleptik meliputi warna, bau, tekstur dan tingkat kesukaan kepada 15 panelis dengan menggunakan angket tertutup. Analisis data menggunakan analisis varian (anava) dua jalur melalui SPSS versi 17.0 dengan taraf signifikan 0,05, kemudian jika signifikan akan dilanjutkanuji BNT atau LSD. Hasil analisis menunjukkan variasi konsentrasi berpengaruh terhadap kadar glukosa $(\mathrm{P}=0,000$ $<0,05)$. Lama perendaman berpengaruh terhadap kadar glukosa( $\mathrm{P}=0,000<0,05)$. Terdapat pengaruh interaksi variasi konsentrasi dan lama perendaman terhadap kadar glukosa $(\mathrm{P}=0,013<0,05)$. Kadar glukosa tertinggi terdapat pada perlakuan $\mathrm{K}_{1} \mathrm{~L}_{1}$ (konsentrasi 1\% dan lama perendaman 60 menit), sedangkan kadar glukosa terendah pada perlakuan $\mathrm{K}_{3} \mathrm{~L}_{2}$ dan $\mathrm{K}_{3} \mathrm{~L}_{3}$ pada perendaman 120 menit.Hasil uji organoleptik yang disukai pada perlakuan $\mathrm{K}_{3} \mathrm{~L}_{3}$ karena bau khas garut hilang, warna lebih putih, tekstur sangat lembut dan kadar glukosanya rendah.
\end{abstract}

Kata Kunci : Asam Laktat, garut (Maranta arundinacea L), Kadar Glukosa

\section{PENDAHULUAN}

Kondisi masyarakat Indonesia yang tergantung pada bahan pangan tertentu misalnya beras dan gandum dapat melemahkan ketahanan pangan nasional. Satu kenyataan yang cukup mengkhawatirkan adalah pada periode Januari-April 2005, terjadi lonjakan impor terigu menjadi 176 ribu ton dari semula 98 ribu ton pada tahun 2004 di periode yang sama, dan diperkirakan selama tahun 2005 sampai tahun 2006 akan menjadi dua kali lipat dibandingkan tahun 2004 (Anonim, 2005 dalam Yovita, 2007).
Kebutuhan masyarakat yang besar terhadap terigu memicu terjadinya impor dengan jumlah yang cukup besar. Indonesia memiliki sumber pangan lokal yang tersedia cukup banyak dan belum dimanfaatkan secara optimal, untuk mengurangi ketergantungan tepung terigu impor adalah dengan mensubstitusi bahan pangan lokal yang ada di indonesia. Komoditas lokal yang berpotensi untuk di olah menjadi tepung adalah garut. Umbi garut akan cepat busuk apabila tidak segera di olah menjadi makanan. 
Umbi garut kemudian dapat diproses menjadi tepung atau pati termodifikasi. Dalam bentuk tepung, umbi-umbian dapat difortifikasi dengan berbagai zat gizi yang diinginkan. Umbi garut dijadikan tepung untuk mempermudah dan memperpanjang daya penyimpanan hingga dapat tahan berbulan-bulan, bahkan hingga tahunan. Garut dalam bentuk tepung akan mempermudah mengolahnya menjadi berbagai jenis makanan siap saji dan menyesuaikannya dengan selera yang disukai (Sylvia dan Mar'attus, 2009).

Karakteristik kimia dan fisik tepung garut masih kurang baik serta karakteristik sensori seperti aroma, rasa, dan tekstur dari umbi garut masih terasa sehingga perlu adanya modifikasi melalui fermentasi (Karjono, 1998 dalam Yoas, Lindayani, Laksmi., 2012).

Memodifikasi tepung berbasis umbi garut dengan perendaman asam laktat, sehingga didapatkan komposisi tepung garut fermentasi yang mendekati karakteristik tepung terigu. Asam asetat dan asam laktat adalah asam organik yang aman digunakan sebagai preservatif makanan. Berdasarkan penelitian, asam organik adalah substansi antimikrobial yang digunakan dalam pangan dan oleh FDA telah diakui aman digunakan sebagai preservatif bahan makanan. Penambahan preservatif diharapkan dapat memperpanjang masa simpan dan mencegah kerusakan pada bahan pangan (Andriani, Darmono, Widya, 2007).

Asam laktat aman digunakan sebagai preservasi (Anomimus, 2001 dalam Andriani et al., 2007) dan lebih efektif digunakan sebagai bahan preservasi karena tidak ada batas maksimal penggunaannya. Penggunaan asam asetat dan asam laktat dalam jangka waktu lama tidak membahayakan kesehatan karena dapat dimetabolisir oleh tubuh dan diekskresikan (Suprapto dan Dian., 2006 dalam Andriani, Darmono, Widya., 2007).

\section{METODE}

Penelitian menggunakan metode Rancangan Acak Lengkap (RAL) disusun secara dua faktorial dengan tiga kali ulangan. Faktor perlakuan meliputi faktor I konsentrasi asam laktat dan faktor II lama perendaman asam laktat, kemudian menghasilkan 9 kombinasi perlakuan. Faktor I adalah perlakuan konsentrasi asam laktat 1\%, 1.5\% dan $2 \%$. faktor II adalah lama perendaman asam laktat selama 60 menit, 90 menit dan 120 menit. Data yang digunakan pada penelitian adalah data uji kadar glukosa dan kualitas tepung garut yang meliputi warna, bau dan tekstur. Data didapatkan dengan teknik atau cara analisis kuantitatif. Data kadar glukosa pada tepung garut diperoleh dengan menggunakan metode luff schoorl. Rumus yang digunakan untuk menghitung prosentase kadar glukosa adalah :

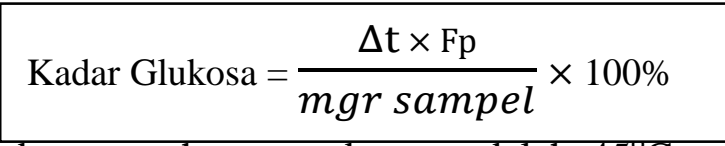

dengan suhu perendaman adalah $45^{\circ} \mathrm{C}$. Lama perendaman asam laktat berbedabeda yakni 60 menit, 90 menit dan 120 menit.

Data kadar glukosa tepung garut yang diperoleh dalam bentuk prosentase kemudian dianalisis dengan anava dua jalan, jika hasil uji hipotesis signifikan (probabilitas (sig < 0,05) maka dilanjutkan dengan uji BNJ (Beda Nyata Jujur). Analisis data untuk anava dua jalan dan BNJ menggunakan SPSS versi 17.

Pengujian kualitas tepung menggunakan metode uji hedonik dengan 15 panelis. Para panelis diminta melihat kualitas tepung garut yang 
diberi perlakuan konsentrasi dan lama perendaman asam lakat. Rumus yang digunakan untuk menghitung nilai organoleptik adalah :

$$
\frac{\text { Warna (30) }+ \text { Bau (20) }+ \text { Tekstur (20) }}{70}
$$

\section{HASIL DAN PEMBAHASAN}

Data prosentase kadar glukosa didapatkan berdasarkan analisis glukosa menggunakan metode Luff Scrool dapat dilihat pada gambar 1 .

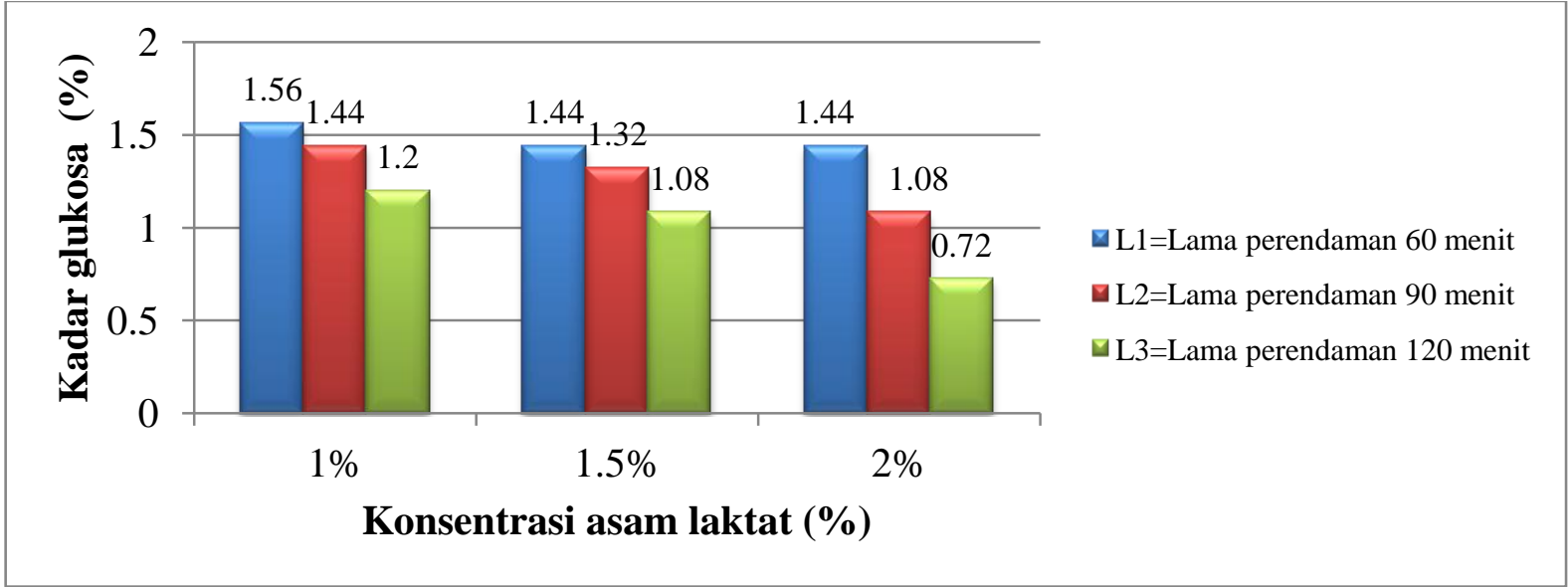

Gambar 1. Histogram hasil uji kadar glukosa tepung garut

Gambar 1 di atas menunjukkan hasil analisis kandungan glukosa pada tepung garut dengan berbagai perlakuan $\mathrm{K}_{1} \mathrm{~L}_{1}$ (konsentrasi asam laktat $1 \%$ dan lama perendaman 60 menit) memiliki kadar glukosa sebesar $1,56 \%$ dan merupakan kadar glukosa yang paling tinggi. Perlakuan $\mathrm{K}_{1} \mathrm{~L}_{3}$ (konsentrasi asam laktat $1 \%$ dan lama perendaman 120 menit) dengan kadar glukosa 0,72\% merupakan perlakuan yang memiliki kadar glukosa terendah.

a. Variasi konsentrasi

Dari gambar 1 menunjukkan bahwa semakin tinggi konsentrasi asam laktat asam laktat berpengaruh terhadap penurunan gula reduksi. Pada tepung garut peningkatan konsentrasi asam laktat berpengaruh karena semakin tinggi konsentrasi asam laktat maka semakin banyak polisakarida yang terhidrolisis dan yang terlarut. Polisakarida berupa amilosa yang terhidrolisis dan terlarut menyebabkan gula reduksi pada tepung garut semakin sedikit.

Hasil penelitian sesuai dengan pendapat atichokudomchaia, et al., (2000) (dalam Pudjihastuti, 2010) menyatakan molekul amilosa mudah terpecah dibanding dengan molekul amilopektin sehingga saat hidrolisa asam berlangsung akan menurunkan gugus amilosa. Penelitian ini menggunakan garut yang dibuat tepung dalam satu proses yang sama, tidak menggunakan tepung yang berbeda proses. Penurunan kadar glukosa terjadi pada setiap perlakuan,meskipun ada perlakuan $\mathrm{K}_{3} \mathrm{~L}_{1}$ dan $\mathrm{K}_{3} \mathrm{~L}_{2}$ yang menunjukkan kadar glukosa sama.

$$
\text { Pada tepung garut terjadi }
$$

kenaikan glukosa pada perlakuan $\mathrm{K}_{2} \mathrm{~L}_{2}$, $\mathrm{K}_{2} \mathrm{~L}_{3}, \mathrm{~K}_{3} \mathrm{~L}_{2}$, dan $\mathrm{K}_{3} \mathrm{~L}_{3}$. Menurut penelitian Yanuwardana (2013) dalam Feny, Bambang, Dimas, (2013) pada tepung labu kuning termodifikasi asam laktat 
menunjukkan semakin besar konsentrasi asam laktat dan semakin lama perendaman maka semakin besar gula reduksinya. Hal ini terjadi karena adanya hidrolisis asam pada pati, dimana pati yang disusun oleh amilosa dan amilopektin akan dipecah oleh asam laktat menjadi gula sederhana. Menurut Graham, et al (1981) (dalam Feny Dwi Hartanti, 2013) menyatakan jika dibandingkan tepung sukun, gula reduksi pada tepung sukun termodifikasi lebih besar karena terjadinya hidrolisis asam.

\section{B. Lama perendaman}

Perlakuan perendaman 60 menit pada perlakuan $\mathrm{K}_{1} \mathrm{~L}_{1}$ memiliki kadar glukosa tertinggi dan lama perendaman 120 menit pada perlakuan $\mathrm{K}_{3} \mathrm{~L}_{3}$ memiliki kadar glukosa terendah. Penurunan glukosa disebabkan Perendaman asam laktat yang semakin lama menyebabkan kandungan glukosa pada tepung garut semakin menurun. Perendaman dengan asam menyebabkan amilosa yang terhidrolisis akan terlarut sehingga semakin lama perendaman menyebabkan semakin menurun gula reduksi (Feny, Bambang, Dimas. 2013).

Data uji organoleptik tepung garut menggunakan skala hedonik untuk mengetahui tingkat kesukaaan panelis terhadap tepung garut. Parameter yang diamati meliputi warna, bau dan tekstur.

Hasil uji organoleptik warna tepung garut mengacu pada skala hedonik yaitu 4 (sangat putih), 3 (agak putih), 2 (putih kecoklatan), dan 1 ( coklat). Pada perlakuan $\mathrm{K}_{3} \mathrm{~L}_{3}$ (konsentrasi $2 \%$ dengan lama perendaman 120 menit) memiliki rata-rata tertinggi yaitu 3,8 berarti termasuk dalam warna sangat putih. Perlakuan $\mathrm{K}_{1} \mathrm{~L}_{1}$ (konsentrasi $1 \%$ dengan lama perendaman 60 menit) memiliki ratarata terendah yaitu 1,7 berarti termasuk dalam warna coklat.

Berdasarkan data tersebut dapat dilihat bahwa semakin tinggi konsentrasi dan lama perendaman asam laktat maka semakin meningkat warna tepung garut menuju skala yang menunjukkan warna putih. Hal tersebut sesuai dengan pendapat Winarno (1992) (dalam Feny Dwi Hartanti,2013), perendaman akan mencegah reaksi maillard pada tepung. Reaksi maillard (pencoklatan non enzimatis) merupakan reaksi yang melibatkan gugus karbonil dan gugus amin. Salah satu cara untuk mencegah terjadinya reaksi pencoklatan dilakukan dengan cara menghambat atau memblokir reaksi antara gugus karbonil atau gula pereduksi dengan gugus amina dengan melakukan perendaman.

Hasil dari uji organoleptik bau dari tepung garut mengacu pada skala hedonik yaitu 4 (tidak berbau), 3 (agak kuat), 2 (kurang kuat), dan 1(sangat kuat). Pada perlakuan $\mathrm{K}_{3} \mathrm{~L}_{3}$ (konsentrasi 2\% dengan lama perendaman 120 menit) memiliki rata-rata tertinggi 3,7 sedangkan $\mathrm{K}_{1} \mathrm{~L}_{1}$ (konsentrasi $1 \%$ dengan konsentrasi $1 \%$ ) memiliki rata-rata terendah yaitu 1,2. Hal tersebut menunjukkan bahwa konsentrasi dan lama perendaman asam laktat mempengaruhi bau dari tepung uwi dari mula-mula memiliki bau khas garut yang kuat menjadi tidak berbau. Hasil penelitian ini sesuai dengan penilitian Sarpina et.,al dalam Yoas, Lindiyani, Laksmi (2012) menyatakan bahwa senyawa asam akan bercampur denngan tepung, sehingga menghasilkan aroma dan cita rasa yang khas yang dapat menutupi cita rasa dari umbi yang cenderung tidak disukai oleh konsumen.

Hasil dari uji organoleptik tekstur dari tepung garut yang mengacu pada skala hedonik yaitu 4 (lembut), 3 (agak lembut), 2 (agak kasar) dan 1 (Kasar) menunjukkan perlakuan $\mathrm{K}_{3} \mathrm{~L}_{2}$ (konsentrasi 2\% dengan lama perendaman 120 menit) memiliki rata-rata tertinggi 3,8 berarti termasuk dalam agak lembut namun mendekati lembut, sedangkan $\mathrm{K}_{1} \mathrm{~L}_{1}$ (konsentrasi $1 \%$ dengan lama perendaman 60 menit) memiliki rata-rata terendah yaitu 2,2 berarti termasuk dalam tekstur agak kasar. Variasi konsentrasi dan lama perendaman tidak mempengaruhi secara signifikan terhadap tekstur tepung garut karena pada setiap perlakuan memiliki rata-rata yang mendekati skala 3 dan 4 . Hal tersebut berarti tekstur tepung lembut. Adapun nilai organoleptik tepung garut dapat dilihat pada gambar 2 . 


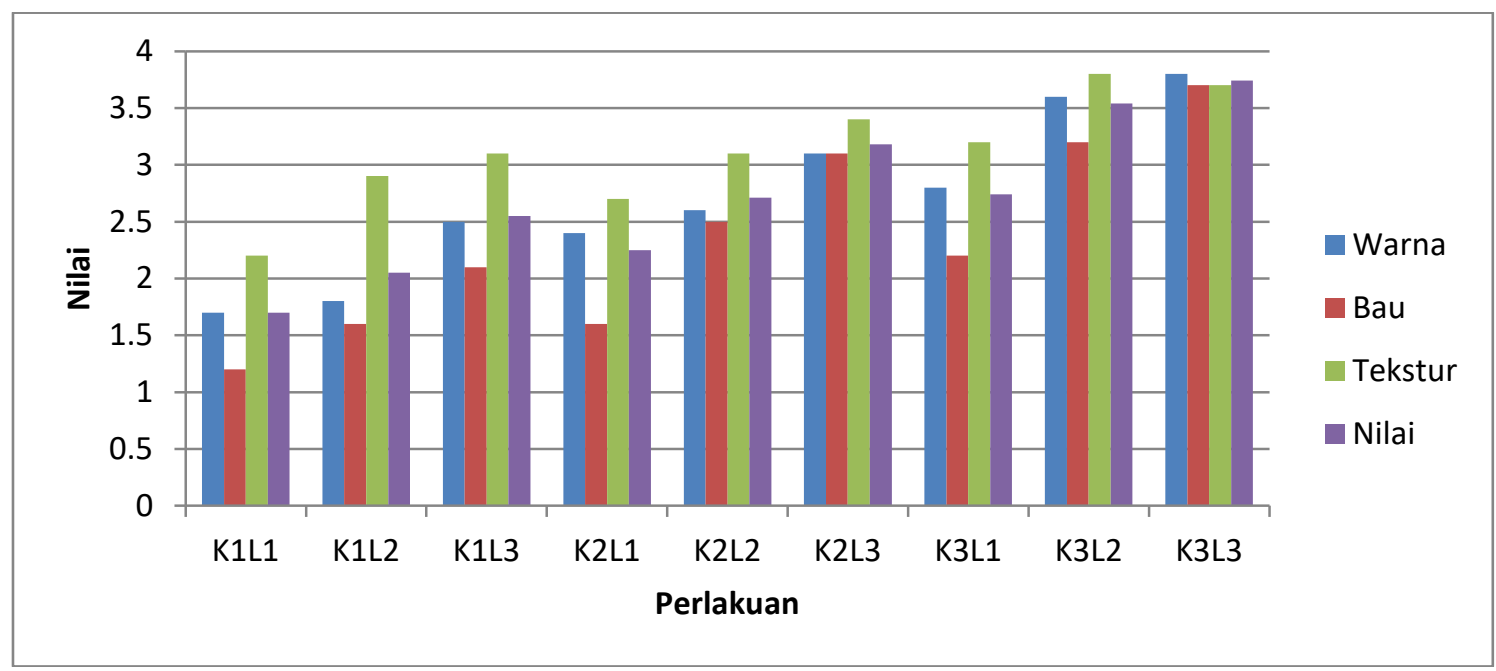

Gambar 2. Histogram uji organoleptik tepung garut

Gambar 2 menunjukkan perlakuan $\mathrm{K}_{1} \mathrm{~L}_{1} \quad$ (konsentrasi $1 \%$ dan lama perendaman 60 menit) memiliki nilai terendah yaitu 1,70 berarti tingkat kesukaan panelis rendah. Perlakuan $\mathrm{K}_{3} \mathrm{~L}_{3}$ memiliki nilai tertinggi yaitu 3,74 berarti kualitasnya baik karena semakin tinggi nilai atau tingkat kesukaan panelis maka kualitas tepung semakin baik. Dari hasil perhitungan nilai terjadi peningkatan pada setiap perlakuan, semakin besar konsentrasi dan lama perendaman, semakin tinggi nilai. Sehingga semakin besar konsentrasi dan lama perendaman, semakin tinggi tingkat kesukaan panelis dan semakin baik kualitas tepung.

\section{SIMPULAN}

Dari hasil penelitian pengaruh konsentrasi dan lama perendaman terhadap kandungan glukosa dan kualitas tepung garut (Maranta arundinacea L) dapat di ambil simpulan sebagai berikut : variasi konsentrasi berpengaruh nyata terhadap kandungan glukosa tepung garut (Maranta arundinacea L), lama perendaman berpengaruh nyata terhadap kandungan glukosa tepung garut (Maranta arundinacea L), variasi konsentrasi dan lama perendaman berpengaruh nyata terhadap kandungan glukosa tepung garut, semakin tinggi konsentrasi dan lama perendaman asam laktat maka tepung garut semakin disukai panelis.

\section{DAFTAR PUSTAKA}

E-gumbira sa'id.1987.Penerapan teknologi fermentasi.Jakarta:Penerbit PT Melton Putra.

Feny, Bambang dan Dimas.2013.Kajian karakteristik fisikokimia tepung sukun (Artocarpus communis) termodifikasi dengan variasi konsentrasi dan lama perendaman asam

laktat.www.ilmupangan.fp.uns.ac.i d.Diakses tanggal 17 Februari 2014.

Isti Pudjihastuti.2010.Pengembangan proses inovatif kombinasi reaksi hidrolisis asam dan reaksi photokimia uv untuk produksi pati termodifikasi dari tapioka.http://eprints.undip.ac.id.Di akses tanggal 2 Juli 2014.

Sugiyono.2013.Metode penelitian pendidikan.Bandung:Penerbit Alfabeta.

Universitas Sumatra Utara.Uraian asam laktat.http://repository.usu.ac.id.Di akses tanggal 26 Februari 2014.

Universitas Sumatra utara.2012.Definisi glukosa.http://jtptunimus-gdlumiaminatu-6537bab2glukosa.Diakses tanggal 8 Maret 2014.

Very.2012.Hubungan antara gaya hidup sehat dengan pencapaian prestasi akademik 
mahasiswa.http://keperawatan.unso ed.ac.id.Diakses tanggal 3 April 2014.

Yovita.2007.Substitusi tepung gandum (Triticum aestivum) dengan tepung harut (Maranta arundinaceae L) pada pembuatan roti tawar.http://muhammadsubchi.files .wordpress.Diakses tanggal 26 Februari 2014.

Yoas Masadi, Lindayani, dan Laksmi Hartayanie.2010.Karakter kimia dan fisik tepung garut(Maranta arundinacea)hasil fermentasi dan aplikasinya sebagai alternatif pengganti tepung terigu dalam pembuatan pasta instan.http://eprints.unika.ac.id.Dia kses tanggal 26 Februari 2014. 